\title{
Cave Ecosystems: Microbiological View
}

\author{
Begum Candiroglu', Nihal Dogruoz Gungor ${ }^{2 *}$ \\ 'Istanbul University, Institute of Health Sciences, Istanbul, Turkey \\ ${ }^{2}$ Istanbul University, Faculty of Science, Department of Biology, Istanbul, Turkey
}

Please cite this article as: Candiroglu B, Dogruoz Gungur N. Cave Ecosystems: Microbiological View. Eur J Biol 2017; 76(1): 36-42.

\begin{abstract}
The mysterious passages known as caves between the earth and the underworld are important geological forms that can be investigated for several astonishing facts. The caves that we define as cavities or gaps into which a person can enter are usually visited by people for several different purposes. Caves are important for studies on environments in terms of biology and geology due to their extreme conditions. In Turkey, there are about 35.000-40.000 caves, most of which have not been mapped or scientifically explored. The mechanisms by which living creatures survive in these cave environments, adapt to the extreme conditions, and develop for survival have been the topics of research. Microorganisms and physical factors are responsible for the occurrence and formation of different geological forms such as stalactites, stalagmites, and cave pearls in these extreme environments. This fact makes the caves more interesting in terms of their microbiology. Studies on cave microbiology have been aimed at exploring the functions of these microorganisms and new ones unique to the cave habitats. On the other hand, these environment-specific microorganisms carry a great potential to possess new and different enzymes or antimicrobial substances. The discovery of new features and new microorganisms is also important as it adds new information to the science of systematics. The topics on caves and their microbiology, which have been studied by few researchers throughout the world, are less commonly studied in Turkey. The protection of the cave environment while people enter into them for touristic, sports, and scientific causes is of historical and scientific importance. In this context, the protection of caves is an issue that requires caution in obtaining both correct and new results from the environment and the study of caves. Cave sportsmen, researchers, and related authorities must adhere to the rules to protect the unique habitat of each cave and prevent earth-borne pollution from entering into the cave.
\end{abstract}

Keywords: Cave ecosystems, microbiology, karst

\section{INTRODUCTION}

Caves, the mysterious and one of the most interesting earth formations on the planet, have been used, studied, and researched by people for several purposes from the past to the present. Caves are subterranean cavities that have a suitable entrance for crawling by at least one person, and their lengths and depths range from a few meters to thousands of meters $(1,2)$. Caves are extreme environments, and the microorganisms living in the cave are adapted to cave conditions and are generally unique. Studies on cave microbiology generally investigate the microbiological diversity in the cave and the metabolic properties of these microbes. These environment-specific microorganisms also carry new and different enzymes or an- timicrobial substances. Because of these reasons, cave habitats have become very interesting environments for microbiologists.

\section{DEFINITION OF CAVES}

Caves are humid, dark environments, and the oxygen level is very low compared to that at the surface. It is also known that several different creatures live in the caves, whose features have not yet been identified (3). Furthermore, $10 \%$ of caves are believed to have been reported in the world $(4,5)$

In Turkey, two-fifths of the land is covered with karstic carbonate and sulfated rocks (Figure 1). It is the top most among the European countries in terms of rich- 


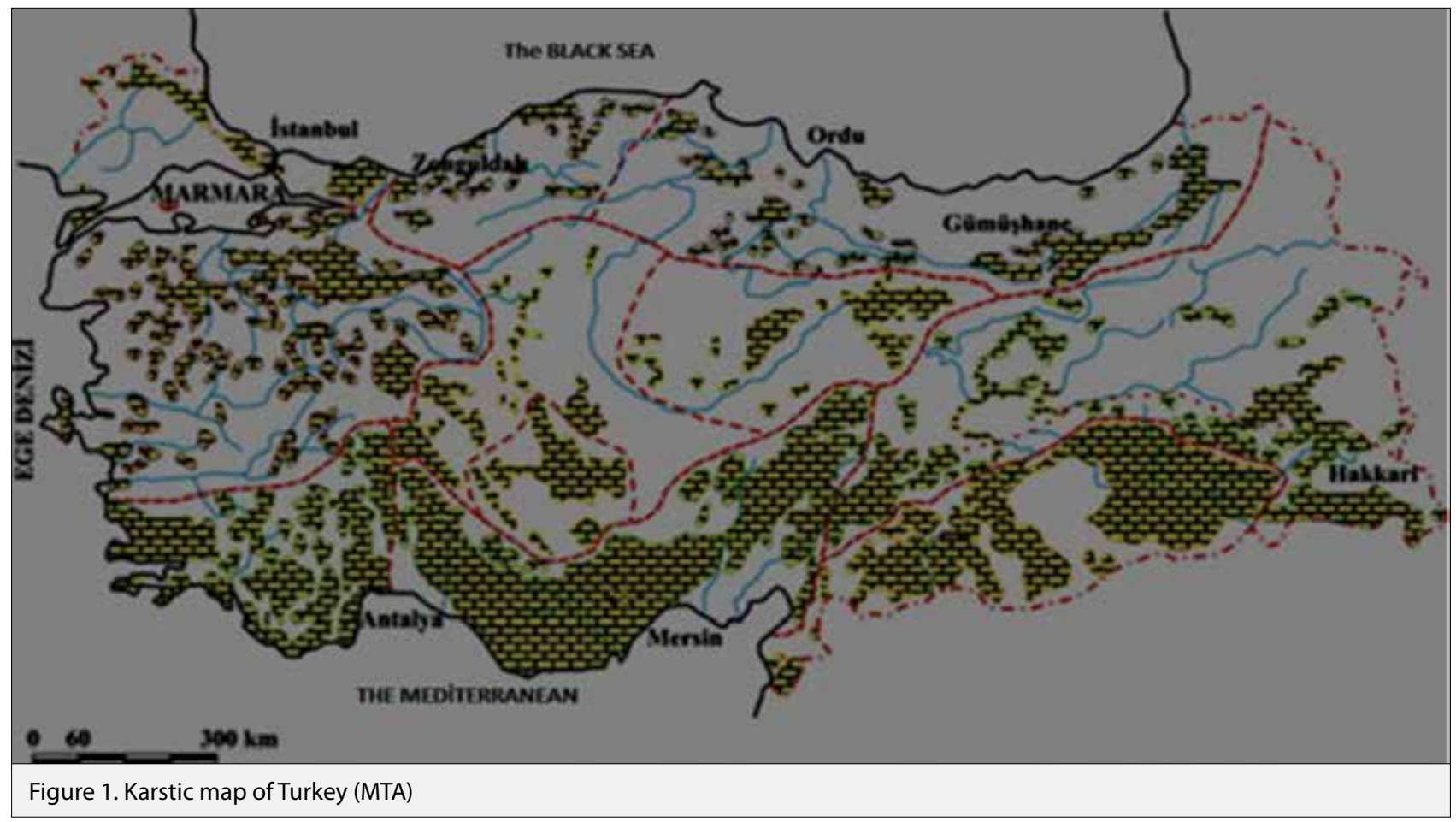

ness of karstic areas. Although all caves in Turkey have not yet been discovered, studies conducted in karstic areas have estimated that there are around $35.000-40.000$ caves in the country (6). An inventory of Turkish caves has been prepared and updated continuously within the framework of the Turkish Archaeological Settlements (TAY) Project, one of the works of the Foundation for the Preservation of the Heritage of History, Archeology, Art, and Culture (TASK). The information of almost 3,500 caves, their layouts, plans, and pictures has been recorded and enlisted in this inventory (7).

Based on the formations, natural caves are of two major types, primary and secondary. Primary caves are formed at the same time as the primary rock (lava caves). If the rocky parts of caves such as limestone, gypsum, dolomite, sandstone, and conglomerate are eroded by underground water (karstification), secondary caves are formed. The secondary caves are also known as karstic caves and are known to be biologically richer (1). The caves are also divided into different classes according to the level of development, their size, their location, the effects that they have on karstification, the distribution areas, and their formations. For example, Pınargözü Cave is the longest cave, measuring $16,000 \mathrm{~m}$ in length that is known today in Isparta town of Turkey and this cave has not yet been completely explored. The deepest cave that has been completely explored is Peynirlikönü Cave in Mersin, with a depth of 1,429 $\mathrm{m}$ (7).

\section{CAVE FORMATIONS}

Caves can be distinguished from each other by several different features, and karstic caves are one of the widest and the most common among these. One of the curious questions about caves is how cave formations occur? Cave formations such as stalagmites and stalactites are caused largely by ions collected by water passing through the bedrocks, and life is also possible in caves through the organic matter present in water. Due to the formation of molten carbon dioxide in the water, the carbon ions in the cave contain carbon dioxide, which is lost due to heat, decrease in pressure, and evaporation, and $\mathrm{CaCO}_{3}$ collapses to form cave structures such as stalagmites and stalactites, which are also known as speleothems (8). The karstification process varies depending on the structure of the soluble rock in the cave and the characteristics of the rainwater inflows, depending on the climatic conditions. The caves are important environments for geological cave discoveries; studies on ecosystem and cave creatures such as bats, arthropods, and microorganisms; as well as understanding the theories about the formation of life in the world and life in space (9).

However, although these geochemical processes play a major role in cave formations, studies have shown that microbial activities also contribute to cave shaping (2,10-14). First, the levels of carbon dioxide, which accelerates the solubility of rocks in the physicochemical formation processes, are increased by plants, animals, and aerobic microorganisms in the cave. Microbial activity has been observed in or on carbonate speleothems in several karstic caverns, and it has been found that microorganisms colonize calcite crystals and other mineral surfaces (15). This indicates an association between microorganisms and crystals. Algae and cyanobacteria in the environment or on the surface change the microclimate by the fixation of carbon dioxide and cause the decomposition 
of calcium carbonate. The microorganisms that appear like lime directly contribute to the growth of speleothems, and they are also identified as the material species of the crystals (16). The calcification microorganisms, characterized by their complex crystal structures, make unique structures and environments because of their unique metabolic processes and products (17). This phenomenon, which occurs passively (18), depending on environmental parameters or microbial calcification with direct effects, continues to occur at all times with the formation of precipitates of new materials added to the surface due to the activities of microorganisms, thereby causing formations such as stalactites. In addition, fungal hyphae have been found in water drops at the end of active stalactites (2).

Furthermore, microorganisms tend to compete or cooperate with each other due to inadequate environments in terms of food and energy of the cave. These competitions and associations result in the formation of secondary metabolites, which are known to play a role in the shape and change of caves $(2,5,19-21)$. Secondary metabolites, including pigments, siderophores, or antibiotics, can cause color change, abrasion, or precipitation that directly affects the microorganisms on the surface $(22,23)$. The effects of microorganisms on mineral cave surfaces include degradation and corrosion events; mechanical effects can occur due to secretion of exoenzymes, organic and mineral acids, and various other mechanisms (24). Especially, the processes of dissolution in caves occur via reactions of bacteria that oxidize iron, sulfur, and manganese. The acid that is bound to microbial interactions causes dissolution in cave walls or speleothems (25).

\section{DIFFERENT ROLES OF MICROORGANISMS IN CAVES}

Besides the effects on cave formations by the microorganisms, it is also important to understand their characteristics and how they adapt to these nutrient-poor environments, in terms of geomicrobiology. Although limited, chemically complex foods enter the cave system, and hence, few microbial species can encode all the necessary uptakes and the catabolic reactions required to support growth. In addition, living in these conditions is possible due to the cooperative partnerships as seen in biofilm communities instead of selfish competition for resources (14). Organic materials that are introduced by people, dripping water, and/or animals, especially bats, allow life for heterotrophic bacteria in caves (26). However, the development of plants and phototrophic microorganisms is hindered by the lack of light in underground environments with limited opportunities for survival. Several studies have shown that chemolithotrophic bacteria (these bacteria provide their energies from the oxidation of chemical compounds such as sulfur and hydrogen sulfide) play a role as primary producers in environments with a complete lack of light radiation and result in the development of heterotrophic microorganisms. On the other hand, cave ecosystems that are the primary producers of sulfur, iron, and manganese oxide have bacteria, sulfate-reducing bacteria, and nitrifying bacteria and are not dependent on organic material inputs $(20,27,28)$. Movile Cave (Romania), Frasassi Caves (Italy), and Lechuguilla Cave (New Mexico, USA) have chemolithotrophic microorganisms as the primary producers $(20,28)$.

Studies conducted in caves, based on microbial cultures, have primarily isolated the following bacteria: Proteobacteria, Actinobacteria, and Firmicutes groups $(14,29,30)$. Lee et al. (3) constructed the $16 \mathrm{~S}$ rRNA phylogenetic tree of the cave. Based on these results, Proteobacteria, Chlorobi/Bacteroidetes, Actinobacteria, and Chloroflexi have been identified as the most common bacterial classes. However, these results can vary according to the characteristics of each cave. Gammaproteobacteria and Acidobacteria dominated the predominant groups in Wind Cave in the USA, while Gammaproteobacteria and Epsilonproteobacteria dominated in the sulfidic cave biofilm (31,32). Zhou et al. (30) compared the caves in Australia, China, Spain, and the USA and reported that Proteobacteria was the dominant group in Spain and China caves and Acidobacteria was the second dominant group. Cave ferromanganese deposits contain some archaea groups, which include mesophilic Crenarchaeota and Euryarchaeota, and this group of archaea has been reported in different studies $(31,33)$. On the other hand, some studies on the geomicrobiology of fungi in tourist caves and isolated caves in different countries have shown that Ascomycota is a predominant group in both culture-dependent and culture-independent studies (34-37).

Caves can also be referred to as extreme environments because they provide a living space for highly specialized microorganisms (3). The high microbial diversity of caves indicates that each cave has its own characteristics. The geology of caves, their geography, rock structures, and conditions (temperature, light, humidity, water, organic matter, $\mathrm{pH}$, and inorganic structure of the inner surface of the cave) make each cave unique with a different cave ecosystem $(2,27,38)$. On the other hand, it is worth determining the microbial diversity of a cave and increasing the microbial discoveries and the ecological mobility on earth.

\section{WHAT IS THE IMPORTANCE OF STUDYING CAVE MICROOR- GANISMS?}

The research topic of microbial diversity also carries the potential for the discovery of rare microorganisms living in the cave environments. In environments containing complex microorganisms, the number of bacteria that can be cultured for special nutrient requirements is only $0.1-1 \%$ of the total number. Caves are extreme environments with the potential to discover new creatures, to uncover new gene pools, and to name and replicate in culture $(39,40)$. For making new discoveries that antibiotics and new species of microorganisms, it is very important to determine the microbiological diversity of a newly discovered cave and identify from where it is sampled to the point of microbiological sampling from the first introduced/footed regions of the caves. It is also important that the sampling is done by cave biologists to ensure that it is done correctly. It is normal to find 
surface bacteria in the water coming into the cave from the surface; however, it is not correct to say that these microorganisms are specific to the cave ecosystem. Samples taken from water, sediments, and cave formations isolated from the cave surface are more accurate examples for investigating cave-specific microorganisms. Cave researchers have two important roles in cave microbiology. The first is exploring and researching new life and ecosystems in the cave, and the second is protecting the microbial habitat in caves and preventing human-induced contamination.

On the other hand, cave microorganisms have the potential to underpin several biotechnological studies. For example, caves are important work environments for antibiotic discoveries and for understanding antibiotic resistance. Antibiotic resistance genes possessed by microorganisms can provide important results to understand the development of antibiotic resistance (41). It is known that antibiotics that are commonly used today and the wastes produced by their use increase the resistance of microorganisms. There is no resistance to minimal anthropogenic exposure, and there is no evidence of resistance genes in microorganisms isolated from terrestrial animals living in such environments (42). In addition, there are studies that have described the presence of microorganisms with antibiotic resistance, which were isolated from the extremes of natural underground habitats $(43,44)$. These studies provide an additional view of multidrug resistance caused by anthropogenic effects, so that knowledge of resistance can be obtained without adversely affecting the resistance, and it is important to understand the resistance genes and solve the associated clinical problems $(43,45)$. The emergence of different resistance mechanisms paralleled the potential for the acquisition of different antimicrobial substances. The level of antibiotic resistance of microorganisms cultured in a laboratory frequently increases upon the inception of antibiotic biosynthesis (46).

On the other hand, unexplored environments such as caves have a significant potential for exploring new antimicrobial substances because of the increased competition in the environment due to the limited nutrient content, as a result of which the microorganisms produce antimicrobial substances against each other $(2,30,47)$. The discovery of enzymes possessed by microorganisms and antibiotics produced due to the competition among microorganisms obtained from isolated cave environments has been one of the important study subjects that will provide important contributions in industrial and clinical terms (48). Enzymes of several industrial inland microorganisms have been utilized.

The enzymatic products of cave microorganisms are important for food industry, cleaning industry, including cleaning agents such as detergents and biocides, molecular biology studies, and in several features of biotechnology, because these environments have stable cold temperatures throughout the year. Therefore, despite the cold environment property, they can support enzyme production by the microorganisms (49-52).
Good results from cave explorations can be achieved by not detracting the environmental conditions and the peculiar features of the creatures.

It is very important to obtain different scientific data on cave microorganisms and other living things in this extreme environment. However, geologically and biologically, cave studies have been insufficient in Turkey. The biological cave studies that have been carried out are primarily on bats and arthropods of some caves $(53,54)$. Studies on microbiology are much more limited. Barış (55) has done the characterization and description of bacteria that contribute to the formation of dripstone in Elmalı and Yıldızkaya cave systems in Erzurum province. Yücel and Yamaç (56) investigated the antimicrobial activities of Streptomyces spp. from 19 different caves. Şen et al. (57) investigated the antimicrobial activities, statin-producing ability, and the cytotoxic effects of bacterial specimens isolated from Düzkır Cave (Aladağlar) in vitro and tested in vivo in mice.

\section{CAVE ACTIVITIES AND AIMS OF CAVE VISITING}

Caves are primarily visited for sports, touristic, or scientific purposes. The people who are known as cavers may have an aim of studying the geology, archeology, and biology of caves, they discover the caves or prepare maps, they clean up caves, and they can repair some formations in the underground. The important required materials for cavers include primarily special clothes, helmets, and light sources for the caving activity that are safe, and everyone who enter the cave should be educated to not harm the ecosystem. Because caves, primarily the intact ones, have a potential to harbor rare species and may have ancient writings and drawings, there are usually several special formations in caves.

Cave tourism would raise the issue of whether entry of organic materials and microorganisms through outsiders would affect the natural cave communities. The isolation barrier of caves is destroyed due to people entering into the caves, which results in disruption of the balance of the cave habitat. Since the creatures living in the cave are adapted to the conditions of the cave, they are significantly affected even by a slight change that may occur in the cave ecosystem $(2,27,30,38)$. For example, artificial lights placed inside caves encourage the development of phototrophic bacteria, causing changes in the microbiological communities in the cave ecosystem. Similarly, during long-term cave explorations, cavers may have to camp for days, sometimes weeks, in the cave. Such human activities affect the cave ecosystem. Consequently, cavers or cave scientists must also be sensitive about the exchange of cave microbial environments between different caves, i.e., movement between caves is not possible with microbial transport. Therefore, the cavers' clothes must be cleaned during movement between two caves. In addition to the increasing pollution and land development, caves are also affected by human activities on earth and in the underground. Hence, caves and their rare environments should be protected. 


\section{SUBJECTS THAT SHOULD BE TREATED WITH CAUTION RE- GARDING CAVES}

The opening of a cave for tourism is a subject that requires cavers, scientists, and ministries to work together with caution, because the arrangements in the cave must be designed in such a way that the natural environment of the cave would be least affected. However, it is also necessary to take health precautions as well as protect these sensitive ecosystems. Issues such as hypothermia, falling, blunt trauma, sprains and strains, and head injures may be hazardous for cavers. Some studies have also shown that caves can cause certain health problems to humans in addition to these hazardous issues. Because of the environmental conditions, caves can serve as reservoirs for microorganisms such as fungi that thrive in moist environments. Some studies have shown that caves have suitable environmental conditions favorable for the presence and growth of bacteria, fungi, or yeasts carried by caves with water and/or guano, human and/or animal inputs from the earth (29). In addition, viruses and various microorganisms can be transported by bat guano from the outside to caves, which can infect humans by contact or by inhalation. Only few documented pathogens are known to be limited to human species and responsible for causing human infections (58). Approximately $75 \%$ of known infectious human diseases are zoonoses, and the majority are transported from wildlife reservoirs (59). The fungus Histoplasma capsulatum lives in bat guanos, and its ecological niche is influenced by soil, nutrients present in bat guano, and environmental conditions such as temperature and humidity (60). It has been reported that several Actinobacteria species have been isolated in different cave studies. In particular, several species belonging to Nocardia, Mycobacterium, and Rhodococcus have been identified $(61,62)$. These species are known for causing different skin, lung, or brain infections because of the presence of some structures. Even though diseases caused by these bacteria have been primarily reported in immunosuppressed patients, it is possible that they can also infect people whose immune system has not been damaged. In addition, an increase in the amount of people who enter caves is a factor that increases the transport of pathogens (63). Jurado et al. (29) conducted a study to identify potential tourism hazards in the caves and reported that caves constitute a potential danger to the cave visitors due to the possibility of the presence of yet unknown and opportunistic microorganisms. They also stated that cave microorganisms frequently cause respiratory system infections. Thus, it is important to conduct a microbiological analysis of the cave environment before opening a tourist cave.

\section{CONCLUSION}

Coordinated efforts between ministries, sportsmen, scientists, and the people who live around the caves will create elements that could contribute to protection of caves. The unique structures of the cave and the creatures living in this extreme and dark environment should be investigated for several new products and knowledge, which will enlighten both science and industry. Therefore, protecting both caves and their ecologies is very important.

\section{REFERENCES}

1. Palmer AN. Origin and morphology of limestone caves. Geol Soc Am Bull 1991; 103: 1-21. [CrossRef]

2. Northup DE, Lavoie KH. Geomicrobiology of Caves: A Review. Geomicrobiol J 2001; 18: 199-222. [CrossRef]

3. Lee IT, Liu JY, Lin CH, Oyama Kl, Chen CY, Chen CH. lonospheric plasma caves under the equatorial ionization anomaly. JGR 2012; 117(A11): 1-9. [CrossRef]

4. Eavis A. An up to date report of cave exploration around the world, Proceedings of 15th International Congress of Speleology 2009 Kerrville, Texas.

5. Engel AS, Stern LA, Bennett PC. Microbial contributions to cave formation: New insights into sulfuricacid speleogenesis. Geology 2004; 32(5): 369-72. [CrossRef]

6. Maden Tektik ve Arama Genel Mudurluğu http://www.mta.gov.tr/ v3.0/arastirmalar/magara-envanteri

7. Turkiye Arkeolojik Yerlesmeleri Projesiveri Tabanları. "Magara veritabani" http://www.tayproject.org/TAYmaster.fm

8. Gornitz V. Sea level change, post-glacial. Encyclopedia of Paleoclimatology and Ancient Environments. Springer, Dordrecht 2009; 887-92. [CrossRef]

9. Boston PJ, Spilde MN, Northup DE, Melim LA, Soroka DS, Kleina LG, et al. Cave biosignature suites: microbes, minerals, and Mars. Astrobiology 2001; 1(1): 25-55. [CrossRef]

10. Leveille RJ, Fyfe WS, Longstaffe FJ. Geomicrobiology of carbonate-silicate microbialites from Hawaiian basaltic sea caves. Chem Geol 2000; 169: 339-55. [CrossRef]

11. Riding R. Microbial carbonates: the geological record of calcified bacterial-algal mats and biofilms. Sedimentology 2000; 47(Suppl 1): 179-214. [CrossRef]

12. Hammes F, Boon N, de Villiers J, Verstraete W, Siciliano SD. Strain-Specific Ureolytic Microbial Calcium Carbonate Precipitation. Appl Environ Microbiol 2003; 69(8): 4901-9. [CrossRef]

13. Baskar S, Baskar R, Mauclaire L, McKenzie JA. Microbially induced calcite precipitation in culture experiments: Possible origin for stalactites in Sahastradhara caves, Dehradun, India. Curr Sci 2006; 90(1): 58-64.

14. Barton HA, Jurado V. What's Up Down There? Microbial Diversity in Caves. Microbe 2007; 23(3): 132-8.

15. Castanier S, Le Metayer-Levrel G, Perthuisot JP. Ca-carbonates precipitation and limestone genesis-the microbiogeologist point of view. Sediment Geol 1999; 126: 9 -23. [CrossRef]

16. Jones $B$, Kahle CF. Origin of endogeneticmicrite in karstterrains: a case study from the Cayman Islands. J Sediment Res 1995; 65: 283-93.

17. Riding R. Calcified Plectonema (blue-green algae), a recent example of Girvanella from Aldabra Atoll. Palaeontology 1977; 20(1): 33-46.

18. Golubić $S$. The relationship between blue-green algae and carbonate deposits. The Biology of Blue-Green Algae 1973; 434-72.

19. Canaveras JC, Sanchez-Moral S, Soler V, Saiz-Jimenez C. Microorganisms and microbially induced fabrics in cave walls. Geomicrobiol J 2001; 18(3): 223-40. [CrossRef]

20. Chen Y, Wu L, Boden R, Hillebrand A, Kumaresan D, Moussard H, et al. Life without light: microbial diversity and evidence of sulfurand ammonium-based chemolithotrophy in Movile Cave. ISME J 2009; 3(9): 1093-104. [CrossRef]

21. Barton HA. Biospeleogenesis Biogenetic Processes and Microbial Impact on Speleogenesis. Treatise on Geomorphology 2013; (6). Editor: Shroder, J. F. San Diego: Academic Press. 
22. Rajput Y, Biswas J. Subterranean depth dependent protein constitutions of the Micrococcus sp., isolated from the Kotumsar Cave. India. Asian J Biochem 2012; 7: 90-7. [CrossRef]

23. Gabriel CR, Northup DE. Microbial ecology: caves as an extreme habitat. In Cave microbiomes: a novel resource for drug discovery. Springer New York 2013; 85-108. [CrossRef]

24. Sand W. Microbial mechanisms of deterioration of inorganic substrates-a general mechanistic overview. Int Biodeter Biodegr 1997; 40: 183-90. [CrossRef]

25. Engel AS, Megan L, Porter BK, Kinkle TC, Kane A. Ecological assessment and geological significance of microbial communities from Cesspool Cave, Virginia. Geomicrobiol J 2001; 18: 259-74. [CrossRef]

26. Groth I, Vettermann R, Schuetze B, Schumann P, Saiz-Jimenez C. Actinomycetes in karstic caves of northern Spain (Altamira and Tito Bustillo). J Microbiol Methods 1999; 36(1-2): 115-22. [CrossRef]

27. Sarbu SM, Kane TC, Kinkle BK. A chemoautotrophically based cave ecosystem. Science 1996; 272(5270): 1953-5. [CrossRef]

28. Porter ML, Engel AS, Kane TC, Kinkle BK. Productivity-diversity relationships from chemolithoautotrophically based sulfidic karst systems. Int J Speleol 2009; 38(1): 27-40. [CrossRef]

29. Jurado V, Porca E, Cuezva S, Fernandez-Cortes A, Sanches-Moral S, Saiz-Jimenez C. Fungal Outbreak in a Show Cave. Sci Total Environ 2010; 408: 3632-8. [CrossRef]

30. Zhou JP, Gu YQ, Zou CS, Mo M. Phylogenetic Diversity of Bacteria in an Earth-Cave in Guizhou Province, Southwest of China. J Microbiol 2007; 45(2): 105-12.

31. Chelius MK, Moore JC. Molecular phylogenetic analysis of archaea and bacteria in Wind Cave, South Dakota. Geomicrobiol J 2004; 21: 123-34. [CrossRef]

32. Engel AS. Microbial diversity of cave ecosystems. In: Geomicrobiology: Molecular and Environmental Perspective. Editors: Loy, A., Mandl, M. \& Barton, L. L. New York: Springer 2010; 219-38. [CrossRef]

33. Northup DE, Barns SM, Yu LE, Spilde MN, Schelble RT, Dano KE, et al. Diverse microbial communities inhabiting ferromanganese deposits in Lechuguilla and Spider Caves. Environ Microbiol 2003; 5(11): 1071-86. [CrossRef]

34. Docampo S, Trigo MM, Recio M, Melgar M, Garcia-Sanchez J, Calderon-Ezquerro MC, et al. High incidence of Aspergillus and Penicillium spores in the atmosphere of the cave of Neija (Malaga, southern Spain). Aerobiologia 2010; 26(2): 89-98. [CrossRef]

35. Dupont J, Jacquet C, Dennetiere B, Lacoste S, Bousta F, Orial G, et al. Invasion of the French Paleolithic painted cave of Lascaux by members of the Fusarium solani species complex. Mycologia 2007; 99(4): 526-33. [CrossRef]

36. Kiyuna T, An K, Sano RKC, Miura S, Sugiyama J. Mycobiota of the Takamatsuzuka and Kitora Tumuli in Japan, focussing on the molecular phylogenetic diversity of Fusarium and Trichoderma. Mycoscience 2008; 49(5): 298-311. [CrossRef]

37. Nagai K, Suzuki K, Okada G. Studies on the distribution of alkalophilic and alkali-tolerant soil fungi II: fungal flora in two limestone caves in Japan. Mycoscience 1998; 39: 293-8. [CrossRef]

38. Sarbu SM, Lascu C. Condensation corrosion in Movile cave, Romania. J Caves Karst Stud 1997; 59(3): 99-102.

39. Amann RI, Ludwig W, Schleifer KH. Phylogenetic identification and in situ detection of individual microbial cells without cultivation. Microbiol Rev 1995; 59(1): 143-69.

40. Winogradsky S. Microbiologie du sol: problèmes et méthodes. 861 . 1949, Paris: Masson.
41. Knapp CW, Dolfing J, Ehlert PA, Graham DW. Evidence of increasing antibiotic resistance gene abundances in archived soils since 1940. Environ Sci Technol 2010; 44(2): 580-7. [CrossRef]

42. Thaller MC, Migliore L, Marquez C, Tapia W, Cedeno V, Rossolini GM, et al. Tracking acquired antibiotic resistance in commensal bacteria of Galapagos land iguanas: no man, no resistance. PLoS One 2010; 5(2): 8989. [CrossRef]

43. Bhullar K, Waglechner N, Pawlowski A, Koteva K, Blanks ED, Johnson $\mathrm{MD}$, et al. Antibiotic resistance is prevalent in an isolated cave microbiome. PLoS One 2012; 7(4): e34953. [CrossRef]

44. Brown MG, Balkwill DL. Antibiotic resistance in bacteria isolated from the deep terrestrial subsurface. Microb Ecol 2009; 57(3): 48493. [CrossRef]

45. D'costa VM, McGrann KM, Hughes DW, Wright GD. Sampling the antibiotic resistome. Science 2006; 311(5759): 374-7. [CrossRef]

46. Martin JF, Demain AL. Control of antibiotic biosynthesis. Microbiol Rev 1980; 44(2): 230-51.

47. Dapkevicius MLNE. Cave biofilms and their potential for novel antibiotic drug discovery. In: Cheeptham n, ed. cave microbiomes: $\mathrm{A}$ novel resource for drug discovery. Springer Briefs in Microbiology 2013; 1: 85-108.

48. Ehrlich Marie-France. Metacognitive monitoring in the processing of anaphoric devices in skilled and less skilled comprehenders. Reading comprehension difficulties: Processes and Intervention 1996; 221-49.

49. Cabeza MS, Baca FL, Puntes EM, Loto F, Baigorí MD, Morata VI. Selection of psychrotolerant microorganisms producing cold-active pectinases for biotechnological processes at low temperature. Food Technol Biotechnol 2011; 49(2): 187-95.

50. Cavicchioli R, Charlton T, Ertan H, Omar SM, Siddiqui KS, Williams TJ. Biotechnological uses of enzymes from psychrophiles. Microb Biotechnol 2011; 4(4): 449-60. [CrossRef]

51. Gerday C, Aittaleb M, Bentahir M, Chessa JP, Claverie P, Collins T, et al. Cold-adapted enzymes: From fundamentals to biotechnology. Trends Biotechnol 2000; 18(3): 103-7. [CrossRef]

52. Russell NJ. Molecular adaptations in psychrophilic bacteria: potential for biotechnological applications. Adv Biochem Eng Biotechnol 1998; 61: 1-21. [CrossRef]

53. Paksuz S, Ozkan B, Postawa T. Seasonal changes of cave-dwelling bat fauna and their relationship with microclimate in dupnisa cave system (Turkish Thrace). Acta Zool Cracov 2007; 50: 57-6. [CrossRef]

54. Guher H. A Faunistic Study on the Freshwater Cladocera (Crustacea) Species in Turkish Thrace (Edirne, Tekirdağ, Kırklareli). Turk J Zool 2000; 24(3): 237-43.

55. Baris O. Erzurum Ilindeki Magaralarda Damlatasi Olusumunda Etkili Bakterilerin İzolasyonu, Karakterizasyonu Ve Tanısı 2009, Ataturk Universitesi Doktora Tezi.

56. Yucel S, Yamac M. Selection of streptomyces isolates from Turkish karstic caves against antibiotic resistant microorganisms. Pak J Pharm Sci 2010; 23(1): 1-6.

57. Sen M, Bayburt C, Aydın S, Onder NI, Incesu Z, Atli B, Yamac M. Duzkır Magarasından (Aladaglar) Elde Edilen Bakteri Izolatlarının Biyolojik Aktiviteleri, 2011. 5. Ulusal speleoloji sempozyumu, 18-21 Mart, İstanbul.

58. Roche B, Guégan JF. Ecosystem dynamics, biological diversity and emerging infectious diseases. C R Biol 2011; 334(3-6): 385-92. [CrossRef] 
59. Field HE. Bats and emerging zoonoses: henipaviruses and SARS. Zoonoses Public Health 2009; 56(6-7): 278-84. [CrossRef]

60. Emmons CW. Association of bats with histoplasmosis. Public Health Rep 1958; 73(7): 590-5. [CrossRef]

61. Nasher MA, Hay RJ, Mahgoub ES, Gumaa SA. In vitro studies of antibiotic sensitivities of Streptomyces somaliensis-a cause of human actinomycetoma. Trans RI Soc Trop Med Hyg 1989; 83(2): 265-8. [CrossRef]
62. Jurado V, Boiron P, Kroppenstedt RM, Laurent F, Couble A, Laiz L, et al. Nocardia altamirensis sp. nov., isolated from Altamira cave, Cantabria, Spain. Int J Syst Evol Microbiol 2008; 58(Pt 9): 2210-4. [CrossRef]

63. Li L, Victoria JG, Wang C, Jones M, Fellers GM, Kunz TH, et al. Bat guano virome: predominance of dietary viruses from insects and plants plus novel mammalian viruses. J Virol 2010; 84(14): 6955-65. [CrossRef] 